\title{
Recent Invasion of the Endemic Banggai Cardinalfish, Pterapogon kauderni at The Strait of Bali: Assessment of the Habitat Type and Population Structure
}

\author{
I Nyoman Giri Putra* and I Dewa Nyoman Nurweda Putra \\ Faculty of Marine Science and Fisheries, Udayana University \\ Kampus Bukit Jimbaran, Badung-Bali, 80361, Indonesia \\ Email: nyomangiriputra@unud.ac.id
}

\begin{abstract}
The demands of marine organisms for the aquarium trade are remain high and seems continue to increase. Consequently, many of marine organisms has been spread out from its natural habitat as in the case of endemic Banggai cardinalfish, (Pterapogon kauderni). That has invaded "new" habitat since it being trade in 1995. In recent years, a small populations of $P$. kauderni is known to be exist in a narrow bay near the Gilimanuk harbor, Bali. An underwater visual fish census survey was conducted on June 2018 to estimate the habitat types and densities of P. kauderni. Additionally, 23 specimens of P. kauderni were collected randomly in order to assess biological parameters such as the length-weight relationship. We successfully recorded 30 groups of $P$. kauderni that inhabit a shallow areas with a depth range between $0.5 \mathrm{~m}$ to $2 \mathrm{~m}$. Of these, more than $90 \%$ of the groups were found to be associated with sea urchin (Diadema sp.) while the rest were found to live together with branching coral (Acropora sp.) and branching sponge (Ptylocaulis sp.). Total number of fish observed during the survey were 381 individuals. The fish density is 0.76 individu. $\mathrm{m}^{-2}$. Length-weight relationship showed that $P$. kauderni exhibit is negative allometry $(b<3)$ which mean that the increase in length is faster than the weight gain. Interestingly, from the 23 specimens collected, none of these were sexually mature (SL<41 mm) which may indicated that the population of $P$. kauderni in Bali are under serious threats of exploitation.
\end{abstract}

Keywords: Bali, Banggai cardinalfish, endemic, introduced, invasion

\section{Introduction}

The Banggai cardinalfish, Pterapogon kauderni is an endemic species limited to the Banggai Islands, Central Sulawesi. The limited natural distribution of this species is thought to be due to short pelagic larval phases and limited egg production (Allen, 2000). Since being traded in an aquarium in 1995, demand for $P$. kauderni continuing to increase this species has been heavily collected from the wild. Moreau and Lunn (2004) revealed that approximately 118,000 Banggai cardinalfish were sold on the market every month due to the weakness of the trade monitoring system of this species. Based on data from IUCN Red List, the $P$. kauderni population is continue to decreased, leading to calls for inclusion of this species as an endangered species (Allen and Donaldson, 2007). Another impact arising from aquarium trade is the spread of marine biota beyond its natural habitat.

Introduction of marine species beyond its natural distribution has been widely documented as in macroalgae (Mineur et al., 2008), seagrasses (Williams, 2007; Short et al., 2010), crustaceans (Hänfling et al., 2011), and reef fishes (Butterfield et al., 2015; Albins and Hixon, 2008). In aquatic systems, ballast-water transfer by ocean going vessels has been identified as a leading invasion pathway (Carlton and Geller, 1993). Other factor that has received little attention is the introduction of ornamental species through aquarium trade (Semmens et al., 2004; Weigle et al., 2005; Rhyne et al., 2017). As one of the world's largest ornamental fish exporting countries, Indonesia exported about 1,284 fish species with the number of more than 6 million individuals and 413 species of invertebrates with the number of more than 1.8 million individuals (Rhyne et al., 2017). Unfortunately, despite the growing number of species exported, management trade of these ornamental species are not regularly monitored (Moreau and Lunn, 2004) and the frequency of fish rejection remain high especially for village-based fisheries (Militz et al., 2016). The release of any rejected fish could leads to the introduction of species beyond their natural distribution as in the case of invasion of the P. kauderni in Lembeh Strait, North Sulawesi (Erdmann and Vagelli, 2001); Luwuk, Central Sulawesi (Vagelli and Erdmann, 2002); Palu Bay, Central Sulawesi (Moore and Ndobe, 2007) and Bali (Allen and Erdmann, 2012). 
The introduction of alien species has a serious impact on local species communities and reduced biodiversity from over-exploitation (Albins and Hixon, 2008). The introduction of carnivorous fish generally has a negative impact on the ecosystem because the fish are likely to prey on local fish and invertebrates or become competitors to local predators (Albins and Hixon, 2008). Other impacts arising from the invasion of alien species are changes in ecosystem functions (Hänfling et al., 2011). But other studies suggest that invasions could accelerating the material cycle and increasing habitat availability (Thomsen, 2010). Although studies of the mechanisms, impacts, and factors that triggered the invasion have been studied quite extensively, the invasion by endemic fish is seems to be unusual and least information is known about it.

The endemic $P$. kauderni is known to have invaded Bali Strait around the Secret Bay, Gilimanuk. Secret Bay area is a narrow bay with a depth of about 10 meters which is ecologically quite unique compare to other areas in Bali (Allen and Erdmann, 2012). This region consist of various ecosystem such as seagrasses, corals and mangroves. Present data of the $P$. kauderni population in Secret Bay are based only on a brief survey conducted in 2012 that showed the number of these species were 1,000 individuals and found to be associated with sea urchins (Allen and Erdmann, 2012). Naturaly, P. kauderni is known to be associated with various biota such as sea urchins, corals, sea stars, anemones, fishes and mangroves (Vagelli and Erdmann, 2002). Since being introduced, population of the $P$. kauderni in Gilimanuk seem continuing to flourish even though this species is regularly collected by the local fisherman. Therefore, this study aimed to studying invasion of the endemic Banggai Cardinal fish and their population structure in the Bali Straits.

\section{Materials and Methods}

The underwater visual census fish surveys were conducted during June 2018 in two sites, geographically located on $-8.16491 \quad 114.44025$ (Site 1) and -8.16951, 114.44699 (Site 2) (Figure 1). At each site, transect was set in shallow water at a depth between $0.5 \mathrm{~m}$ to $2 \mathrm{~m}$. All transects were 50 meters long and it is assumed that the diver can observe fish up to 5 meters along transect (2.5 meters to each side) (English et al., 1994). The location of transect at each site was set in the main areas of the $P$. kauderni identified by local fishermen. At each site the following data were recorded: the number of fish groups, the number of fish in each groups, and the habitat types along transect.

The regulation of the Ministry of Marine Affairs and Fisheries Republic of Indonesia number 49/KEPMEN-KP/2018 protect $P$. kauderni around their natural distribution in Banggai Islands. Based on this regulation, the introduced population are not protected yet, thus no special collection or research permits were necessary during specimen collection in Bali Strait. $P$. kauderni were collected randomly from two sites around Secret Bay, Gilimanuk (Figure 1) with a small fyke net used by the local ornamental fishermen. The specimens were preserved in $70 \%$ alcohol for transportation and storage.

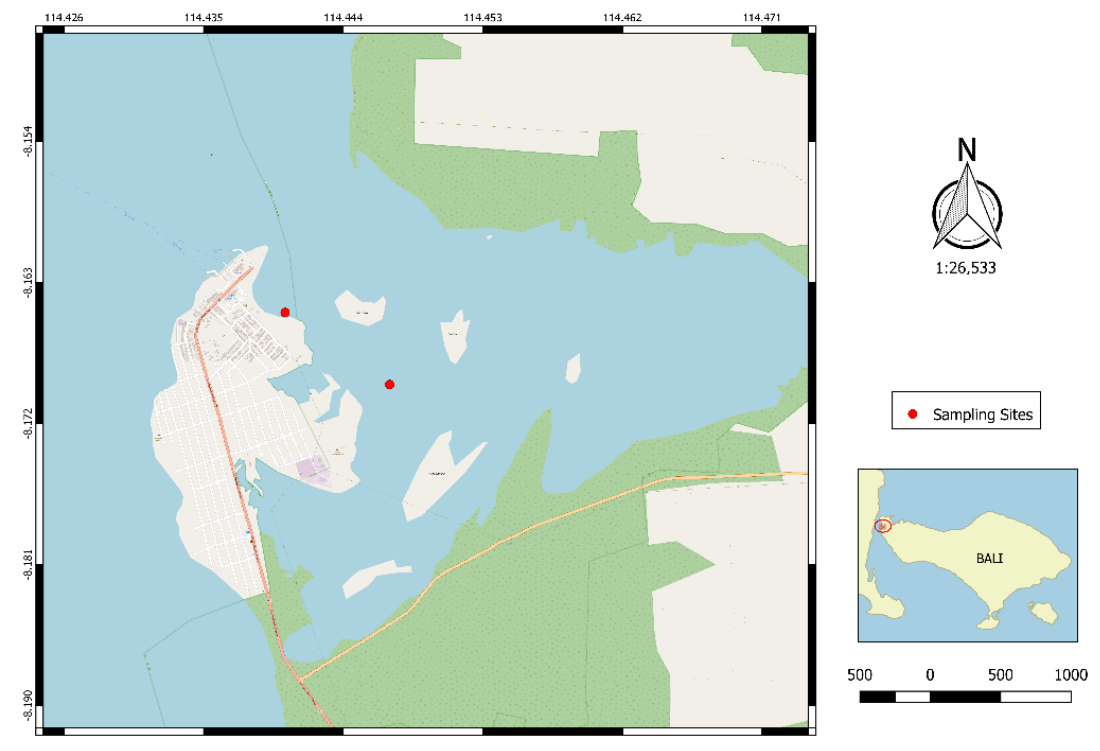

Figure 1. Fish survey located at a semi-enclosed bay near the Gilimanuk Port, Bali 
Fish population density at each transect was calculated using the formula (Odum, 1993): $D=\frac{n}{w}$ Where: $D$ is the fish population density (ind. $\mathrm{m}^{-2}$ ), $n$ is the number of individual and $w$ is coverage area. Length-weight relationship can be used to predict weight at a given length. Mathematically, this relationship is described by the formula (Ricker, 1973): $W=a \cdot L^{b}$. Where: $W$ is the wet weight in gram, " $a$ " and " $b$ " are the parameters of the function and $L$ is the standard length (SL) in millimeter. The length frequency data was obtained by dividing the sample length (SL) into some groups and then calculating the number of individuals within the groups.

\section{Results and Discussions}

\section{Habitat types}

P. kauderni in the Bali Strait was found in a semi-enclosed bay near the Gilimanuk Port. The bottom substrates of the bay were composed of sands, coral rubbles, and rocks. During the survey, we recorded that $P$. kauderni inhabiting a shallow area with a depth range between 0.5-2 m. Previous research also showed that $P$. kauderni was commonly found in protected bays on a shallow area (Allen, 2000). In addition, a comprehensive survey conducted to determine the geographical distribution of $P$. kauderni revealed that this species was found at depth range between $0.5 \mathrm{~m}$ and $4.5 \mathrm{~m}$, with an average depth recorded of $1.66 \mathrm{~m}$ (Vagelli and Erdmann, 2002). Thus, P. kauderni populations in the Bali Strait seems to have a similar habitat characteristics compared to their natural habitat in Banggai Islands although these newly established population shows some interesting differences. In Banggai Islands, $P$. kauderni was known to be associated with several species of corals (Acropora sp., Anacropora sp., Porites sp., Goniopora sp., Echinopora horrida, Heliofungia actiniformis, Montipora digitata, Seriotopora hystrix, and Nephthea sp.); anemones (Actinodendron sp., Entacmaea quadricolor, Heteractis crispa, Macrodactyla doreensis, Stichodactyla haddoni and Stichodactyla merteensis); sea urchins (Diadema setosum, Tripneustes sp.); sea stars (Proteaster nodosus); hydrozoans (Millepora sp.); seagrasses (Enhalus acoroides); and mangroves (Rhizophora sp.) (Vagelli and Erdmann, 2002). Further, this research also revealed that $44 \%$ of the $P$. kauderni in Banggai was associated with branching corals. In contrast to previous one, present study found that more than $90 \%$ of the $P$. kauderni in Bali were associated with sea urchin (Diadema sp.) (Figure 2.). A different condition was observed in Palu Bay, where this species occupies an area totally lacking of Diadema sp. (Moore and Ndobe, 2007). In addition, given the high number of associate species of the $P$. kauderni in their natural geographic distribution (Vagelli and Erdmann, 2002), population in Bali Strait seem possessed a less associate species. For instance, we recorded only four associated species such as sea urchin (Diadema $s p)$, coral (Acropora sp.), sponge (Ptylocaulis sp.), and cardinalfish (Apogonidae) (Figure 3.).

As a species with an extremely limited natural distribution, $P$. kauderni have been succeed to develop outside their natural geographic

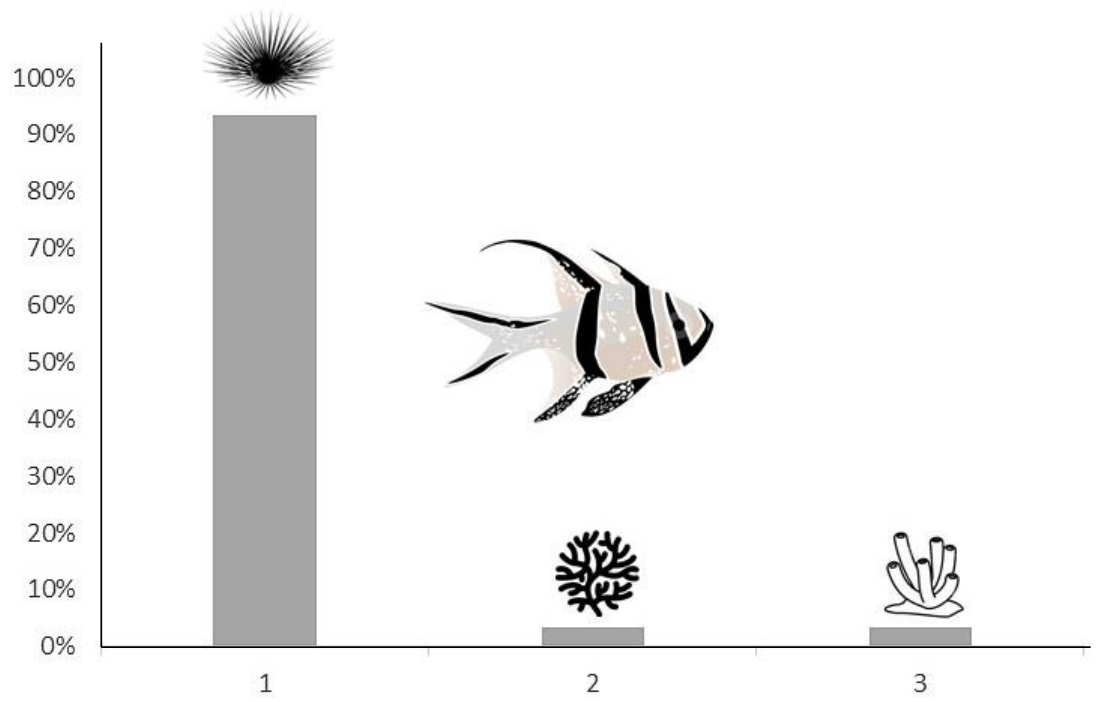

Figure 2. Current proportion of the association between $P$. kauderni and other biota such as sea urchin (1), coral (2), and sponge (3) 


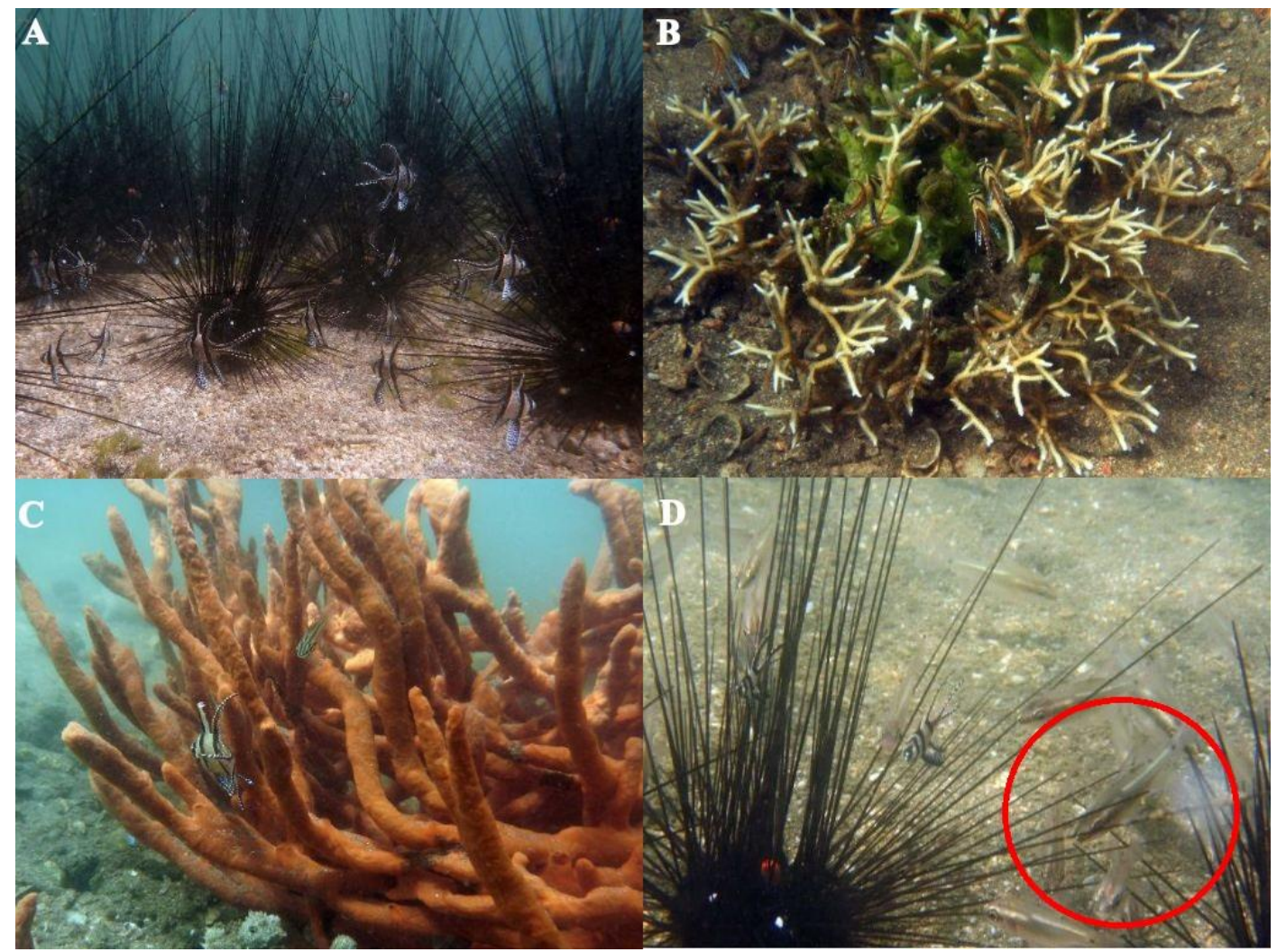

Figure 3. Association between P. kauderni and other biota such as sea urchin (A), branching coral (B), sponge (C), and cardinalfish (indicated by a red circle) (D)

distribution, including Lembeh Strait, North Sulawesi (Erdmann and Vagelli, 2001); Luwuk, Central Sulawesi (Vagelli and Erdmann, 2002); and Palu Bay, Central Sulawesi (Moore and Ndobe, 2007). Those areas were possibly have a different environmental condition compared to their natural habitat but $P$. kauderni appears quite tolerant to environmental changes and pollution (Vagelli and Erdmann, 2002). For instance, this species have been found inhabiting an area with a high risk of contamination derived from the human activities (Vagelli and Erdmann, 2002). On the other hand, a small population of $P$. kauderni in the Palu Bay also known to living in area with a low salinity level compared to those in Banggai Islands (Moore and Ndobe, 2007). Meanwhile, habitats of $P$. kauderni in Bali Strait which is located near the Gilimanuk port are potentially contaminated by the human activities.

\section{Densities and population structure}

The underwater visual census fish surveys showed that the number of group found in Site 1 was 20 groups with the number of individual per group ranging from 3-133 individuals (Table 1.). The total number of individuals found in this site were 344 individuals with a density of 1.4 individuals. $\mathrm{m}^{-2}$.
In contrast, population size of $P$. kauderni at site 2 is seems to be lower than the previous site. At this site, we only found 10 groups with the number of individual per group ranging from 2-6 individuals. The total number of individuals were 36 individuals with a density of 0.1 individuals $\mathrm{m}^{-2}$. Overall, we found 30 groups with the mean group size 12.7 individuals/groups and the average densities of 0.76 individuals $\mathrm{m}^{-2}$ (Table 1).Within its natural geographic range $P$. kauderni formed groups with a mean of 21.28 individuals, although the majority of them were composed of fewer individuals (Vagelli and Erdmann, 2002). Meanwhile, an introduced population of $P$. kauderni found in Lembeh Strait has smaller average group size of 5.8 individuals (Erdmann and Vagelli, 2001).

The number of individual between groups recorded at this present study ranged from $2-133$ individuals.groups ${ }^{-1}$. An introduced population of $P$. kauderni in Palu Bay also showed nearly similar groups size that ranged from 2-200 individuals/groups (Moore and Ndobe, 2007) but the native population in Banggai Islands has larger group size that ranged from 2-500 individuals.groups ${ }^{-1}$ (Vagelli and Erdmann, 2002). Thus, the introduced population including Bali Strait populations were seem to characterized by a lower 
number of individual and group size compared to native population in Banggai Islands. Further, the density of Bali Strait population also lower than the native population. For instance, the densities of $P$. kauderni in Banggai Islands were ranged from 0.5-3 ind. $\mathrm{m}^{-2}$ (Yahya et al., 2012).

Alien population of $P$. kauderni in the Lembeh Strait, Luwuk, Palu Bay, and Bali Strait may have established since few years ago following trading activities which have been started in 1995 . The release adult individuals fish from the holding cages of an aquarium fish exporter should be consist of a small number individuals and firstly, they have adapt to their new environments. Therefore, those may responsible for the lower number of fish, fish density, and fish group size observed at the introduced sites including Bali Strait. Collection of this species by local fisherman might also contribute to the lower number of individuals observed (Moore and Ndobe, 2007; Yahya et al., 2012). Fishing activities, degradation of microhabitat and collection of the associate biota such as sea urchin and anemone also cause a decline in $P$. kauderni densities (Kasim et al., 2016).

The measurements of the length frequency showed that $P$. kauderni in Bali can be categorized into six length classes. The length were ranged from
12.9 to $29.7 \mathrm{~mm} \mathrm{SL}$ with majority classes were found at length between 19.1-22.1 $\mathrm{mm}$ and between 25.3 to $28.3 \mathrm{~mm}$ (Figure 4) while the latest length classes (28.4-31.4 mm) contain the lowest number of individual. The Length-weight relationship equation of $P$. kauderni is $\mathrm{W}=0.0002 \mathrm{~L} 2.5269$ with the coefficient of determination value $\left(R^{2}\right)=0.8778$ (Figure 5). Thus, the value of $b$ obtained from the equation is 2.5269. The t-test at a significant level of $95 \%$ showed that the value of $b<3$ (negative allometry) which means that the increase in length is faster than the weight gain.

The population of $P$. kauderni in the wild has been decline about $89 \%$ since the start of the aquarium fisheries (Allen and Donaldson, 2007). Major threats for this species were came from exploitation which has significantly decrease the population size of P. kauderni (Yahya et al., 2012; Kasim et al., 2016). Over exploitation might also declining genetic diversity or in some cases totally erase a subpopulation (Madduppa et al., 2018). P. kauderni potentially vulnerable to those event since this species occupied a restricted area and exhibit a highly genetic structure which mean the majority of the populations were genetically isolated from one another (Bernardi and Vagelli, 2004; Hoffman et al., 2005). Therefore, recently Ministry of Marine Affairs and Fisheries Republic of Indonesia has been

Table 1. Population size and densities of $P$. kauderni in each sites

\begin{tabular}{lllll}
\hline No. & Observed parameter & Site 1 & Site 2 & Mean \\
\hline 1 & Number of groups & 20 & 10 & 15 \\
2 & Number of individual in each groups & $3-133$ & $2-6$ & 12.7 \\
3 & Total number of individual recorded & 344 & 36 & 190.5 \\
4 & Species density (ind./ $\mathrm{m}^{2}$ ) & 1.4 & 0.1 & 0.76 \\
\hline
\end{tabular}

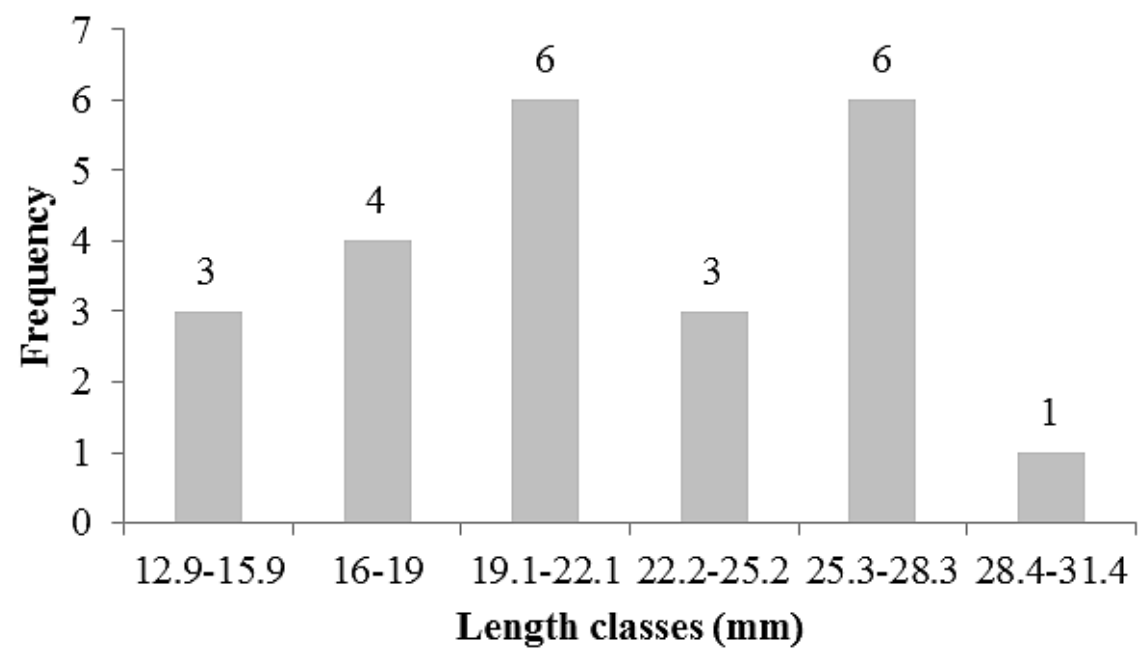

Figure 4. Length frequency of $P$. kauderni collected in Bali Strait 


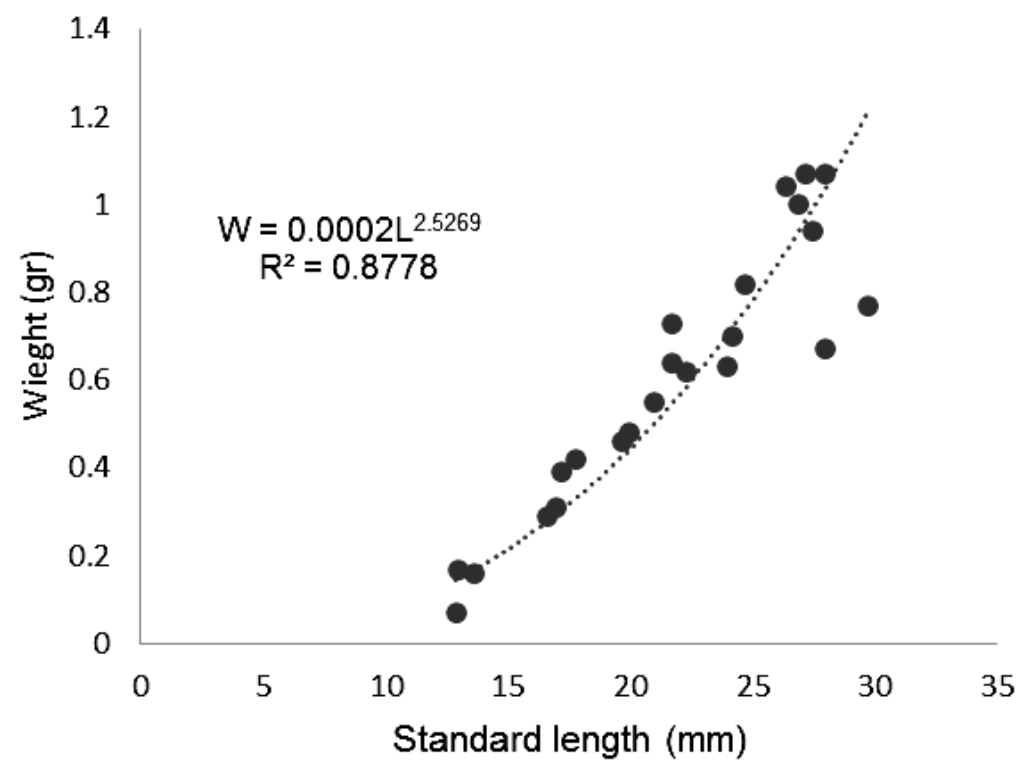

Figure 5. The Length Weight Relationship of $P$. kauderni in The Bali Strait

marked P. kauderni in Banggai Islands as protected species through regulation number 49/KEPMEN$\mathrm{KP} / 2018$. Unfortunately, the regulation has not included the introduced population even though the later also exhibit major exploitation (Moore and Ndobe, 2007). P. kauderni in Bali Strait may also facing the same problem as the population mostly consist of small individuals $(<30 \mathrm{~mm} \mathrm{SL})$. This population appears to be exploited, as medium sized fish (30-40 $\mathrm{mm} \mathrm{SL}$ ), the size preferred by the trade, were periodically rare. According to Vagelli \& Volpedo (2014), P. kauderni showing gonadal maturity was at $41 \mathrm{~mm}$ SL. Thus, $P$. kauderni collected in Bali Strait probably were not sexually mature yet.

\section{Conclusions}

Invasion of the endemic species with a very restricted distribution is a rare cases and interesting subjects to study in relation to their ability to adapt in the new environments. Here, we found that the introduced $P$. kauderni in the Bali Straits possess some interesting differences compare to their natural population in the Banggai Islands regarding to their habitat and population structure. P. kauderni in the Bali Straits is highly associated with Diadema (sea urchin). Interestingly, the population of P.kauderni in the Bali Strait is characterized by low individual number within group and the majority of fishes recorded were a small fishes (<30 $\mathrm{mm} \mathrm{SL}$ ) which may indicate this species are being heavily exploited.

\section{References}

Albins, M.A. \& Hixon, M.A., 2008. Invasive IndoPacific lionfish Pterois volitans reduce recruitment of Atlantic coral-reef fishes. Mar. Ecol. Prog. Ser. 367: 233-238. doi: 10.3354/ meps07620

Allen, G.R., 2000. Threatened fishes of the world: Pterapogon kauderni Koumans, 1933 (Apogonidae). Environ. Biol. Fishes 57(2): 142 doi: 10.1023/A:1007639909422

Allen, G.R. \& Donaldson, T.J., 2007. Pterapogon kauderni, The IUCN Red List of Threatened Species 2007. doi: 10.2305/IUCN.UK.2007. RLTS.T63572A12692964.en

Allen, G.R. \& Erdmann, M.V., 2012. Reef Fishes of Bali, Indonesia, in: Mustika, P., Ratha, I., Purwanto, S. (Eds.), The 2011 Bali Marine Rapid Assessment (Second English Edition August 2012). RAP Bulletin of Biological Assessment 64. Denpasar, p. 137 pp.

Bernardi, G. \& Vagelli, A., 2004. Population structure in Banggai cardinalfish, Pterapogon kauderni, a coral reef species lacking a pelagic larval phase. Mar. Biol. 145: 803-810. doi: 10.1007/ s00227-004-1355-1

Butterfield, J.S.S., Díaz-Ferguson, E., Silliman, B.R., Saunders, J.W., Buddo, D., Mignucci-Giannoni, A. a., Searle, L., Allen, A.C. \& Hunter, M.E., 2015. Wide-ranging phylogeographic structure 
of invasive red lionfish in the Western Atlantic and Greater Caribbean. Mar. Biol. 162(4): 773-781. doi: 10.1007/s00227-015-2623-y

Carlton, J.T. \& Geller, J.B., 1993. Ecological Roulette: The Global Transport of Nonindigenous Marine Organisms. Science. 261(5117)78-82.

English, S., Wilkinson, C. \& Baker, V., 1994. Survey Manual for Tropical Marine Resources. Australian Institute of Marine Science (AIMS), Townsville, Australia.

Erdmann, M.V. \& Vagelli, A., 2001. Banggai cardinalfish invade Lembeh Strait. Coral Reefs 20:252-253. doi:10.1007/s003380100174

Hänfling, B., Edwards, F. \& Gherardi, F., 2011. Invasive alien Crustacea: Dispersal, establishment, impact and control. BioControl 56: 573595. doi: 10.1007/s10526-011-9380-8

Hoffman, E.A., Kolm, N., Berglund, A., Arguello, J.R. \& Jones, A.G., 2005. Genetic structure in the coral-reef-associated Banggai cardinalfish, Pterapogon kauderni. Mol. Ecol. 14(5):13671375. doi: 10.1111/j.1365-294X.2005.0253 8. $\mathrm{x}$

Kasim, K., Hartati, S.T. \& Thordarson, G., 2016. Impacts of fishing and habitat on the density of Banggai cardinalfish (Pterapogon kauderni, Koumans 1933) in Banggai Archipelago, Indonesia. United Nations University Fisheries Training Programme, Iceland.

Madduppa, H.H., Timm, J. \& Kochzius, M., 2018. Reduced Genetic Diversity in the Clown Anemonefish Amphiprion ocellaris in Exploited Reefs of Spermonde Archipelago, Indonesia. Front. Mar. Sci. 5:1-8. doi: 10.3389/fmars.20 18.00080

Militz, T.A., Kinch, J., Foale, S.\& Southgate, P.C., 2016. Fish rejections in the marine aquarium trade: An initial case study raises concern for village-based fisheries. PLoS One 11: 1-15. doi: 10.1371/journal.pone.0151624

Mineur, F., Johnson, M.P. \& Maggs, C.A., 2008. Nonindigenous marine macroalgae in native communities: a case study in the British Isles. J. Mar. Biol. Ass. UK. 88(4): 693-698

Moore, A. \& Ndobe, S., 2007. Discovery of an introduced Banggai Cardinalfish population in
Palu Bay, Central Sulawesi, Indonesia. Coral Reefs. 26(3): 569. doi: 10.1007/s00338-0070227-9

Moreau, M.A. \& Lunn, K.E., 2004. Unmonitored trade in marine ornamental fishes: the case of Indonesia's Banggai cardinalfish (Pterapogon kauderni). Coral Reefs. 23(3): 344-351. doi:10.1007/s00338-004-0393-y

Odum, E.P., 1993. Dasar-Dasar Ekologi. Yogyakarta: Gadjah Mada University Press

Rhyne, A.L., Tlusty, M.F., Szczebak, J.T. \& Holmberg, R.J., 2017. Expanding our understanding of the trade in marine aquarium animals. Peer J. 5: e2949. doi: 10.7717/peerj.2949

Ricker, W.E., 1973. Linear regression in fisheries research. J. Fish. Res. Board Canada. 30: 409 434.

Semmens, B.X., Buhle, E.R., Salomon, A.K. \& Pattengill-semmens, C. V, 2004. A hotspot of non-native marine fishes: evidence for the aquarium trade as an invasion pathway. Mar. Ecol. Prog. Ser. 266: 239-244. doi: 10.3354/meps266239

Short, F.T., Moore, G.E. \& Peyton, K.A., 2010. Halophila ovalis in the Tropical Atlantic Ocean. Aquat. Bot. 93(3): 141-146. doi: 10.1016/j. aquabot.2010.05.001

Thomsen, M., 2010. Experimental evidence for positive effects of invasive seaweed on native invertebrates via habitat-formation in a seagrass bed. Aquat. Invasion 5:341-346.

Vagelli, A.A. \& Erdmann, M.V., 2002. First comprehensive ecological survey of the Banggai cardinalfish, Pterapogon kauderni. Environ. Biol. Fishes 63(1):1-8. doi: 10.1023 /A:1013884020258

Vagelli, A.A. \& Volpedo, A.V., 2004. Reproductive ecology of Pterapogon kauderni, an endemic apogonid from Indonesia with direct development. Environ. Bio. Fish. 70(3): 235245. doi: 10.1023/B:EBFI.000003 3338.1135 $5 . f 9$

Weigle, S.M., Smith, L.D., Carlton, J.T. \& Pederson, J., 2005. Assessing the Risk of Introducing Exotic Species via the Live Marine Species Trade. Conserv. Biol. 19(1): 213-223. doi: 10.1111/ j.1523-1739.2005.00412.x 
Williams, S., 2007. Introduced species in seagrass ecosystems: Status and concerns. J. Exp. Mar. Bio. Ecol. 350(1-2): 89-110.

Yahya, Y., Mustain, A., Artiawan, N. \& Tlusty, M.F., 2012. Summary of results of population density surveys of the Banggai cardinalfish in the Banggai Archipelago, Sulawesi, Indonesia, from 2007-2012. AACL Bioflux 5(5): 303-308. 